\title{
Görme Yetersizliği Olan Kadınların Üreme Sağlığı Sorunları ve Çözüı Yolları
}

\author{
Aylin TANER*, Özlem DEMIREL BOZKURT**
}

Öz

Görme yetersizliği olan kadınlar, üreme sağlığına yönelik, menstrual siklus, cinsel sağlık, gebelik, doğum şekli, emzirme ve çocuk sahibi olma, aile planlaması, jinekolojik muayene ve yıllık düzenli kontrole gitme sorunlarının yanı sıra sağlık hizmetine erişim, eğitim alma ve bakıma yönelik sorunlar yaşamaktadır. Bu sorunlar ve çözüm yollarına yönelik eğitim ve danışmanlık verilirken optimal düzeyde yarar sağlayabilmek için dokunsal, işitsel materyallerden yararlanılması gerekmektedir. Görme eylemi, bilgi edinmeden sorumludur ve bu organdaki herhangi bir değişiklik, bireyin kapasitesinin azalmasına neden olmaktadır. Sağlık profesyonellerinin görme yetersizliğinin nedenlerini, bireylerin öğrenmelerine olan etkisini bilmeleri, üreme sağlığına yönelik düzenlenecek eğitim planlarının oluşturulmasında yarar sağlayacaktır. Kadınları bilgilendirmek için hazırlanan üreme sağlığına yönelik broşür ve kitapçıkların Braille alfabesi ile yazılması ya da seslendirilmesi görme yetersizliği olan kadınların bilgiye ulaşmalarını kolaylaştırmaktadır. Hemşirelerin görme yetersizliği olan bireylere yaklaşım, eğitim ve danışmanlık verme konularında eğitim alması sağlanmalıdır. Bu derlemenin amacı, bireylerin eğitim/danışmanlık alma şeklini etkileyen görme yetersizliğinin tanımlarına ve nedenlerine dikkat çekerek, kadınların üreme sağlığına yönelik yaşadıkları sorunlar ve çözüm yollarına ilişkin hemşirelerin farkındalığını artırmaktır.

Anahtar Kelimeler: Görme Yetersizliği, Üreme Sağlığı, Kadın, Sorunlar, Çözümler.

\begin{abstract}
Reproductive Health Problems of Women with Visual Impairment and Solutions

Women with visual disability experience problems related to reproductive health, such as menstrual cycle, sexual health, pregnancy, delivery method, breastfeeding and having a child, family planning, visiting for gynecological examination and annual routine check-up, as well as problems related to accessing healthcare services, receiving education and care. When providing education and counseling regarding these problems and their solutions, it is required to utilize tactual and audial materials in order to provide optimal benefit. The act of seeing is responsible for obtaining information and any change in this organ will reduce the individual's capacity. If nurses know the reasons of visual disability and its impact on the individual's learning, this will provide benefit to the formation of educational plans to be arranged for reproductive health. Fact that the brochures and leaflets prepared to inform women about reproductive health are written or vocalized in the Braille Alphabet, enables women with visual disability to reach the information. Nurses should be trained in approaching and providing education and counseling to individuals with visual disability. The aim of this review is to draw attention to the definitions and reasons for a visual disability that affects the way of receiving education/counseling and to raise awareness in nurses related to the problems experienced by women regarding reproductive health and the solutions of these problems.
\end{abstract}

Key Words: Visually Impaired, Reproductive Health, Women, Problems, Solutions.

Geliş tarihi: 05.02.2020

Kabul tarihi: 26.12 .2020

$\mathrm{D}$ ünya Sağllk Örgütü (DSÖ) engelliliği "bir yetersizlik ya da özür nedeni ile yaşa, cinsiyete, sosyal ve kültürel durumlara bağlı olarak kişiden beklenen rollerin kısıtlanması veya yerine getirilememesi” olarak tanımlamaktadır (1). Türkiye'de 2013 yılında alınan Bakanlar Kurulu kararıyla yasal mevzuatta bulunan özürlü, malul, sakat gibi kavramlar kaldırılarak sadece engelli kavramının kullanılmasına karar verilmiştir (2). Dünya nüfususun \%10 ile \%15'ini engelliler oluşturmaktadır (1). DSÖ, dünyada yaklaşık 254 milyon insanın görme bozukluğu ile yaşadığını, bunların 36 milyonunun kör ve 217 milyonunun orta ve şiddetli görme bozukluğunun olduğunu bildirmiştir (3). Birleşmiş Milletler Nüfus Fonu'nun 2015 yılında Dünya Nüfus Günü için belirlemiş olduğu Kırılgan Nüfus Grupları teması için Türkiye İstatistik Kurumu'nun (TÜIK) hazırladığı bildiriye göre gözlük veya lens kullandıkları halde görmede zorluk yaşadığını veya hiç görmediğini beyan edenlerin oranı \%1.4; görmede güçlük çekenlerin oranı erkeklerde \% 1.3, kadınlarda da \%1.5’tir (4). Aile, Çalışma ve Sosyal Hizmetler Bakanlığı Ulusal Engelli Veri Sistemine kayıtlı 2.532 .393 engelli bireyden 281.439'u görme engelli olup, ülkemiz görme engelli oranı 11.1'dir (5). Birleșmiş Milletler Engelli Haklarına Dair Sözleșmesi, engelli bireylerin, cinsel sağlık ve üreme sağlığına yönelik kaliteli sağlık hizmeti alması konusunda dünyadaki tüm bireylerle eşit erişim hakkına sahip olduğunu beyan etmiştir (6). İyi bir eğitim düzeyine sahip olmayan bir bireyin sağlık hizmetine ulaşması ve ulaştı̆̆ında da en doğru şekilde kullanması mümkün değildir (7).

Dünya Sağlık Araştırması, yetersizliği olan bireylerin olmayanlara göre ilkokul bitirme oranlarının ve eğitim sürelerinin daha az olduğunu bildirmektedir. Aynı araştırmada eğitim alma oranlarının, yetersizliği olan kadınlarda erkeklere göre daha az olduğu bulunmuştur (8). Görme yetersizliği olan bireylerin görme keskinlikleri, görme dereceleri, görme düzeyleri farkl111k göstermektedir (9). Yetersizlik kavramı, bir şeyi yapmada yeterli olmama, belirli bir şekilde davranmada sinırlı kapasite olarak tanımlanmaktadır (10). Bireyin görme yetersizliğinin olması, gelişimini ve eğitimden yararlanma durumunu olumsuz olarak etkileyebilmektedir (11). Sağlık profesyonelleri yetersizliği olan kadınların karşılaşabileceği sorunları bilmeli ve bunlara çözüm getirebilecek yeterlilikte olmalıdır (7). Ancak Türkiye'de yetersizliği olan kadınların üreme sağlığına yönelik sınırlı sayıda çalışma bulunmaktadır. Bu yönüyle, ilgili konuda literatürde yer alan boşluğun doldurulması gerekmektedir. Bu derlemenin amacı, sağlık profesyonellerine yönelik, görme yetersizliği olan kadınların üreme sağlığı sorunları ve çözüm yolları konusundaki farkındalıklarını artırmaktır.

*Arş. Gör, Ege Üniversitesi Hemşirelik Fakültesi, Kadın Sağlığı ve Hastalıkları Hemşireliği Anabilim Dalı, İzmir, e-mail: aylintaner@gmail.com ORCID: 0000-0002-3386-4863 **Dr. Öğr. Üyesi, Ege Üniversitesi Hemşirelik Fakültesi, Kadın Sağlığı ve Hastalıkları Hemşireliği Anabilim Dalı, İzmir, e-mail: ozlem.bozkurt@ege.edu.tr ORCID: 0000-0002-7212-9140 


\section{Gelişme}

Ülkemizde görülen göz hastalıklarının en temel nedeni genetik-kalıtım, akraba evliliğidir (9). Akraba evliliği Türkiye’de görece yaygındır. Türkiye Nüfus Sağlık Araştırması (TNSA) 2018 yılı sonucuna göre, kadınların \%24’ü eşleri ile akraba olduklarını beyan etmişlerdir. Akraba evliliği yapan kadınların en çok 15-19 yaş aralığında olduğu da göze çarpmaktadır (12). Akraba evliliği yapmış olanların genetik danışma merkezlerinden yararlanmaları konusunda uyarılması gerekmektedir (11). Adölesan dönemde yapılan akraba evliliklerinin obstetrik sonuçları olumsuz etkilediği ve bu evliliklerden meydana gelen çocuklarda şiddetli zihinsel gerilik, körlük, işitme bozukluğu ve sağırlık sıklığının arttığı görülmektedir (13).

Körlük; görme yetisinin tamamen olmaması ya da büyük ölçüde kaybedilmesidir. Gereken tüm tedaviler yapıldıktan sonra, iyi gören gözünde olağan görme gücünün en fazla 1/10'u bulunan ve görüş açısı 20 dereceyi geçmeyen bireyler "kör" olarak adlandırılmaktadır $(14,15)$. Tam körlük ender rastlanan bir durumdur (9). Görme keskinliği, belli bir mesafeden nesneleri görme ve ayrıntıları ayırt etme yeteneğidir. Görme alanı ise baş çevrilmeden ve gözler oynatılmadan görülebilen bir alan şeklinde ifade edilmektedir. Görme yetersizliğinin yasal tanımı, tıp alanında ve sosyal güvenlik kurumlarınca benimsenmekte olup görme keskinliği ve görme alanı kavramları ile ilişkilidir. Görme yetersizliğinin eğitsel tanımı ise, görme keskinliği kaybında ağır derecede etkilenmiş olup, öğretimi dokunarak okuduğu kabartma yazıyla (Braille alfabesi) ve konuşan kitaplardan dinleyerek sürdürmeye gereksinimi olan bireyler şeklindedir (10).

Görme yetersizliğinin nedenleri; doğum öncesi, doğum anı ve doğum sonrası olarak incelenebilir. Doğumun geç, zor ya da müdahaleli olmasına bağlı oksijensiz kalma ya da beyin kanaması geçirme körlüğe neden olabilmektedir. Doğum sonrası dönemde ise, çiçek, kızıl, kızamıkçık, rubella, A ve B vitamini eksikliği, diabetes mellitus, menenjit gibi hastalıklar görme gücü kaybına ve körlüğe neden olabilmektedir (11). Belirtilen tüm bu nedenler göz önünde bulundurulduğunda doğum öncesi, doğum süreci ve doğum sonrası dönemin etkin yönetiminin görme yetersizliğinin önlenmesinde önemli olduğu görülmektedir. Sağlık Bakanlığı'nın doğum öncesi ve doğum sonrası bakım yönetimi rehberleri doğrultusunda kadınların takip edilmesi ve bakımı önem arz etmektedir.

Doğumun yetkili kişiler tarafından yaptırılması, erken doğan bebeklere kuvözde verilen oksijenin kontrollü verilmesi, sık ve ileri yaşlarda doğumun önlenmesi, akraba evliliğin sakıncaları konusunda toplumun bilinçlendirilmesi gerekmektedir (11).

\section{Görme Yetersizliği Olan Kadınların Yașadı̆̆̆ Üreme Să̆lı̆̆ı Sorunları}

Görme yetersizliği olan kadınlar jinekolojik ve obstetrik bakıma ihtiyaç duymakta ve bu hizmetlere yeteri kadar ulaşamamaktadırlar. Yerel hizmetlerin yetersizliği, maliyetli olması, ulaşım ve iletişim engelleri gibi durumlar sağlık hizmetlerine erişim imkanlarını azaltan faktörler arasında yer almaktadır. Bu nedenle kadınlar, daha sık üreme sağlığı sorunlarıyla karşı karşıya kalma riski taşımaktadırlar $(16,17)$.

Birleşmiş Milletler tüm bireylerin cinsel sağlık ve üreme sağlığına yönelik kaliteli sağlık hizmetine erişimde eşit haklara sahip olduklarını belirtmiş olsa da yetersizliği olan bireyler birçok toplumda hala görmezden gelinmektedir $(6,18)$. Özellikle üreme sağlığı konusunda, kadınlar büyük oranda göz ardı edilmekte, "engelli” ve "kadın” olmanın güçlüklerini de bir arada yaşamaktadırlar (16). Toplumda genellikle yetersizliği olan kadınların zayıf oldukları, aseksüel oldukları veya cinsel yönden aktif olmadıkları, gebelik planlamadıkları ve çocuk sahibi olmak istemedikleri, jinekolojik bakıma ihtiyaç duymadıkları ve ebeveynlikte yetersiz kalacakları gibi pek çok konuda olumsuz ön yargı bulunmaktadır (16). Aynı ön yargı, yeteri şekilde eğitim almalarını da olumsuz etkilemektedir (7).

Görme yetersizliği olan bireylerin, duygusal-cinsel yaşamı, diğer insanlarla aynı cinsel gelişim özelliklerini göstermektedir. Görme yetersizliği, üreme sağlığını etkilememekte ve cinsel ilgiyi azaltmamaktadır. Bezzera ve Pagliuca'nın (2010) Portekiz'de yaptığı çalışmada, görme yetersizliği olan genç kadınların kimliklerini ve toplumdaki yerlerini tanımlamaya çalıştığı, kendi cinselliklerini keşfetmek, cinsel dürtülerini ifade etmek ve duygusal ilişkiyi deneyimlemek için yollar aradıkları belirtilmiştir (19).

Bozkurt ve arkadaşlarının (2017) görme yetersizliği olan kadınlarla yürüttüğü çalışmada, kadınların üreme sağlığında yaşadığı sorunların çoğunlukla akıntı, enfeksiyon, polimenore, hipermenore, bebeğin engelli olması nedeni ile küretaj yaptırma olduğu belirlenmiştir. Bununla birlikte kadınların düzenli jinekolojik muayene olmadığı ve Pap smear testi yaptırmadığı belirtilmiştir. Kadınlar, anne olmanın zor olduğunu, emzirmede, bebeğe ilaç uygulamada ve bakımını sağlamada sorun yaşadıklarını ifade etmişlerdir. Kadınların en çok gebelik için ileri yaşta olma ve genetik açıdan kaygı duyma nedenleriyle anne olmayı planlamadığı belirlenmiştir (20).

Yetersizliği olan kadınlar sağlıkla ilgili temel haklara sahiptirler. Hem bireysel hem toplumsal olarak engelli haklarının farkındalığına varılmalı, onlara saygı gösterilmeli ve onların sorunlarına uygun ve yeteri şekilde çözümler getirilmelidir (7). Bu derlemede, görme yetersizliği olan kadınların yaşayabilecekleri genel ve özel üreme sağlığına yönelik menstrual siklus, cinsel sağlık, gebelik, doğum, emzirme, aile planlaması ve jinekolojik sağlık sorunları ile eğitim alma ve bakıma yönelik sorunlar ve çözüm yolları ele alınmıştır.

\section{Menstrual Siklus Sorunları ve Çözüm Yolları}

Görme yetersizliği olan kadınların menstrual siklus yönetimine yönelik bilgi yetersizliği, ped yerleştirme ve değiştirme konusunda eksik ya da yanlış uygulama ve tutumu, üreme sağlığını etkileyen önemli ve özel bir sorun olarak karşımıza çıkmaktadır (21). Menstrual siklus yönetimi için özellikle görme duyusu oldukça önemlidir. Bu nedenle kadınların menstrual siklusu yönetme ve gören kadınlara göre cinsel/üreme sağlığı sorunu yaşama riski daha yüksek olabilir. Mentruasyon döneminde hijyen ve hijyenik ürünlerin kullanımı ile ilgili sorun yaşanabilmektedir. Pedleri veya tamponları değiştirmek için desteğin yetersiz olması, cilt tahrişi, koku, sızıntı, vajinal ve idrar yolu enfeksiyonları bu kadınlarda yaşanan en sık sorunlardır (22). Kişisel hijyen becerileri açısından tek başına tuvalete gidebilme, ped/tamponlarını kontrol edebilme ve değiştirebilme, kirli pedlerini uzaklaştırabilme durumları değerlendirilmelidir (23). Kanmani ve Ravisankar (2016) Hindistan’ın Tamil Nadu 
Derleme

eyaletinde 468 görme yetersizliği olan kadın ile yaptıkları çalışmada, menstrual sorunlarının görülme sıklığı ve tedavi arama davranışını incelemişlerdir. Kadınların üçte birinden fazlasının kanama problemi yaşadığı ve kadınların sadece \%27'sinin tedavi aldığı belirtilmiştir (24). Yaşar ve arkadaşlarının (2017) Ankara'da yaptığı çalışmada, görme yetersizliği olan kadınların sadece \%33.4'ünün menstrual hijyene yönelik bilgi aldığı, bu konuda bilgi ve uygulamalarında eksikliklerin olduğu belirtilmiştir (25). Dündar ve Özsoy’un (2020) Aydın'da yaptıkları çalışmada, kadınların \%61.5'inin mensturasyon hakkında bilgi sahibi olduğu, yarısından fazlasının annesinden destek aldığı belirlenmiştir. Ayrıca \%44.2'si kıyafetlerine kan bulaşma durumunu fark edememe kaygısı yaşadığını, \%35.9'u sosyal alandaki tuvaletlerde çöp kovası/peçetenin yerini bulmakta zorlandığını, \%20.9'u ped değiştirirken zorluk yaşadığını belirtmiştir (23).

Hemşireler tarafından görme yetersizliği olan kadınlara menstrual dönem yönetimi konusunda dokunsal ve işitsel materyaller ile eğitim verilmelidir. Ped/tampon değişimini yapabilecekleri pozisyonlar anlatılmalı, mutlaka hijyen eğitimi verilmelidir (22). Kullanılan pedin değişimine karar verme konusundaki belirteçler pedin çok ıslak, nemli ya da ağır hissedilmesidir. Menstruasyon kanının kıyafet ya da iç çamaşırına bulaştığını fark edememe durumunda ise daha çok menstruasyon öncesi, vücutta meydana gelen abdominal kramplar, memelerde hassasiyet ve vajinada 1slaklık gibi fizyolojik değişiklikleri izlemeleri önerilmelidir. Menstruasyon başlangıcını belirleme konusunda yakınlarından destek almaları yararlı olacaktır (23). Görme yetersizliği olan kadınlara, siklus takibi yapabilmeleri için mobil telefon uygulamalarından yararlanabilecekleri, menstruasyon kanaması meydana geldiğinde bunun normal akıntıdan daha fazla miktarda olacağı ve kokusunun değişeceği, temiz beyaz peçete ile iç çamaşırına dokunup az görenlerin oluşacak renk değişikliğini fark etmesi ya da peçeteyi koklayarak koku değişikliğini anlayabilecekleri konusunda bilgilendirme yapılmasının da yararlı olacağı düşünülmektedir.

\section{Cinsel Sağllk Sorunları ve Çözüm Yolları}

Toplumsal tutumlar ve engelli olmak kadınların cinsel benlik algısını etkilemektedir. Toplum, görme yetersizliği olan kadınları aseksüel ya da daha az seksüel olarak algılamaktadır. Oysa bu tutumun yanlış olduğu yapılan çalışmalarda gösterilmiştir (16,23). Görme yetersizliği olan kadınlar, cinsel bilgilere ulaşma ve cinsel sağlık konusunda danışmanlık hizmeti alma konusunda diğer kadınlarla aynı haklara sahiptir (26). Ülkemizde yaygın eğitimin, okul çağında başlayan üreme/cinsel sağlık eğitiminin olmaması ve formal üreme/cinsel bilgi kaynaklarının (okul, öğretmenler, uzmanlar, kitaplar vb.) yeterli ölçüde kullanılmaması gibi nedenlerle üreme ve cinsellik alanında ciddi boyutta bir bilgi eksikliği olduğu görülmektedir (27).

Görme engellilerin cinselliğine karşı sergilenen olumsuz tutum maalesef sağlı profesyonellerini de kapsamaktadır. Sağl1k profesyonellerinin görme yetersizliği olan bireylerin cinsel sorunlarından haberdar olmadığı ve cinselliğin önemli bir konu olmadığını düşündükleri zaman, kaliteli hizmet sunma olasılıklarının azaldığı belirtilmektedir (28). Sağlık profesyonelleri, cinsel fonksiyonlar ve güvenli cinsellik konularını tartışarak bireyin cinsel kimliğini değerlendirmeli ve cinsel gereksinimleri ortaya konulup, çözüm yolları geliştirmelidir. Ancak çoğu sağlık profesyoneli cinsellik konularını tartışmaktan kaçınmakta ve bireyleri başka bir sağlık profesyoneline başvurmaları için yönlendirmektedir (16). Öncelikle bu konularda kendilerinin eğitim almaları yararlı olacaktır.

Kadınlara cinsel fonksiyonları konusunda konuşma, sorularını sorma ve çözüm önerilerini değerlendirme şansı verilmelidir. Cinsel aktivite, cinselliğin aşamaları, pozisyonlar ve korunma yöntemleri ayrıntılı olarak tartışılmalıdır. Cinsel danışmanlık bireyin özellikleri göz önünde bulundurularak titizlikle ve uzman personel tarafından yapılmalıdır. Sağlık profesyonelleri görme yetersizliği olan kadınlara nasıl danışmanlık verebilecekleri konusunda donanımlı olmalıdır. Bununla birlikte kurumlarda görme yetersizliği olan bireylere yardımcı olabilecek sesli bilgilendirmelerin yer alması, Braille alfabesi ile yazılmış broşür ve kitapçıkların bulunması, dokunsal model ve maketlerin sağlanması sağlık profesyonellerinin danışmanlığını destekleyen gelişmeler olacaktır (17). Sağlık profesyonelinin danışmanlık esnasında sık sık duraklayarak, tekrar ederek anlatım yapması anlaşılmayı kolaylaştıracaktır (29). Görme yetersizliği olan kadınların cinsel yaşamlarını ifade etmeleri için yollar bulmak, bakım ve hizmet veren hemşirelerin en temel görevlerinden biri olmalıdır (28).

\section{Gebelik, Doğum Şekli, Emzirme ve Çocuk Sahibi Olma ile İlgili Sorunlar ve Çözüm Yollart}

Yetersizliği olan ve olmayan kadınlar arasında çocuk sahibi olma isteklerinin benzer olduğu, ancak yetersizliği olan kadınların gebe kalma niyetlerinin daha düşük olduğu belirtilmektedir. Bloom ve arkadaşlarının (2017) Amerika'da yaptığı çalışmada da yetersizliği olan kadınların, yetersizliği olmayan kadınlara kıyasla gelecekte çocuk doğurmayı hedefleme oranının daha az olduğu belirtilmiştir. Bir yetersizliğe sahip olmak, doğum yapma olasılığını isteğe bağlı azaltmaktadır. Bu sonucu etkileyen faktörlerin; gebelik ve doğum sırasında fiziksel veya duygusal problemlerin artması, ebeveynlikle ilgili finansal ve fiziksel zorlukların meydana gelmesi ve yetersizliği olan kadınların çocuklarına bakma yetenekleri hakkındaki toplumsal ön yargıların problem yaratacağı düşüncesi olduğu vurgulanmıştır (30).

Yetersizliğin anlamı, toplumun verdiği tepkilerle ilgilidir. Dolayısıyla yetersizliği olan bireyin ya da grubun kendisine bakışı değil, toplumun onlara bakışı yetersizliği olan bireyin sosyokültürel yapısını belirlemektedir (2). Doğum, kadınlar için doğal bir olaydır. Gebeliğin son dönemlerinde tüm kadınlar gibi görme yetersizliği olan kadınlar da doğum korkusu yaşarken, engeli nedeniyle sezaryen doğum ve anesteziye ilişkin farklı kaygılar da yaşamaktadır (28). Görme yetersizliği olan kadının çocuk sahibi olma hakkı bakımından diğer kadınlardan bir farkı olmamakla beraber, almaları gereken sağlı hizmeti daha ayrıntılı olmalıdır. Görme yetersizliği olan kadının mevcut durumu eğer genetik aktarım riski taşıyorsa bu konuda uzmanından danışmanlık hizmeti almalıdır. Böyle bir risk yoksa da mevcut durumun olası gebelikte yaratacağı sorunlar tartışılmalıdır. Gebelik isteyen kadının gerekli kontrollerden geçirilmesi önemlidir (7,22). Görme yetersizliği olan gebelere yönelik doğum öncesi dönemde doğum için gerekli ortamın düzenlenmesi ve doğum ekibiyle planlama yapılması önem arz etmektedir. Kadınların obstetrik değerlendirmelerinin yapılması, değerlendirme sonucunda alınan karar ile eğer sezaryen yapılacaksa, sezaryenin yararları açıklanarak endişelerinin azaltılması için çaba gösterilmesi hemşirenin temel sorumluluğudur. Görme 
Derleme

yetersizliği olan kadınlar için hemşire odasına bakan ve ses mesafesinde olan bir oda sağlanması uygun olacaktır (28). Benzer şekilde hemşireler tarafından doğum sonu dönemde de kadının yeteneklerini ve özgüvenini desteklemenin, gereksinimlerini belirleyerek ihtiyaç duyduğu desteği ve bilgiyi sağlamanın önemli olduğu düşünülmektedir.

Görme yetersizliği olan ebeveynler hemşireler tarafından güvenli çocuk bakımı konusunda eğitilmelidir. Yetersizliğine ve görme derecesine göre kadına uygun malzemeler kullanılarak bilgilendirme yapılmalıdır. Gebelik ve doğum süreci tartışılmalı, olası senaryolarla ilgili plan yapılmalıdır. Doğum sonrası ebeveynler için bebeğin hareketlerini algılama ve olası kazaları önleme açısından özel tasarlanmış hareket sensorlu uyarıcılar almaları önerilmelidir. Anneler ile emzirme ve memeyi tutuş pozisyonları ile ilgili motivasyonel görüşme yapılabilir, yetişkin öğretim teknikleri ile uygulamalı danışmanlık verilebilir $(7,17,22)$.

\section{Aile Planlaması ile İlgili Sorunlar ve Çözüm Yolları}

Dünyada üreme çağında binlerce görme yetersizliği olan kadın bulunmaktadır. Bu kadınların tüm kadınlarla aynı şekilde aile planlaması hizmetlerinden yararlanma ve doğurganlıklarını düzenleme hakları vardır (22). Ancak fiziksel erişim engelleri, sosyoekonomik faktörler hem kadınların hem de hizmet sağlayan sağlık profesyonellerinin bilgi eksikliği ve ön yargısı nedeniyle, aile planlaması hizmetleri sunumu yetersiz kalabilmektedir (31). Özellikle görme yetersizliği olan bireylerin hizmet verilen ortama ulaşımını kolaylaştırmak için fiziki düzenlemeler yapılmalıdır (29).

Kenya, Nepal ve Uganda'da yetersizliği olan bireylerin cinsel sağlık ve üreme sağlı̆̆ı ile ilgili yapılan çalışmada, üreme/cinsel sağlık hakkında sınırlı bilgiye sahip oldukları, ancak bilgi edinmeye çok istekli oldukları belirtilmiştir. Bazı katılımcıların vazektomi, tüp ligasyon ve acil kontrasepsiyon yöntemini hiç duymadığı ve kontrasepsiyon konusunda yanlış bilgilere sahip olduğu bulunmuştur. Bu çalışmada, yetersizliği olan bireylerin doğru bilgiye ulaşması gerektiği ve davranışlarında değişiklik yaratabilecek cinsel sağlık ve üreme sağlığı eğitim programları ve materyallerine ihtiyaç olduğu vurgulanmıştır (32). Tejeji ve arkadaşlarının (2017) Etiyopya'da yaptığı çalışmada, görme yetersizliği olan bireylerin aile planlaması yöntemleri ve bunlara nereden ulaşılacağı konusunda sınırlı bilgiye sahip olduğu ve aile planlaması hizmetlerine erişimde engellerle karşılaştığı belirtilmiştir (31). Yimer ve Modiba'nın (2019) Etiyopya'da yaşayan görme ve işitme yetersizliği olan kadınların aile planlaması bilgilerini ve uygulamalarını inceledikleri çalışmada, kontraseptif yöntem kullanımına ilişkin bilgi ve uygulamalarının düşük olduğu ancak işitme yetersizliği olan kadınların görme yetersizliği olanlara göre daha kapsamlı bilgiye sahip olduğu ve aile planlaması hizmetlerinden daha fazla yararlandığı belirtilmiştir. Kadınların çoğunun cinsel yönden aktif olduğu ve modern kontraseptif yöntem kullanmadığı bulunmuştur (26).

Görme yetersizliği olan kadınların aile planlaması yöntemleri konusunda kullanım güçlüğü dışında sınırlılığı bulunmamaktadır (16). Genel olarak tıbbi herhangi bir kısıtlama olmadığı durumlarda uzun etkili ve geri dönüşlü yöntemlerin uygun olabileceği belirtilmektedir (29). Kadının yetersizlik derecesine yönelik bir aile planlaması yöntemi önerilmelidir. Dokunsal materyaller ile aile planlamasına yönelik bilgilendirme yapılması ve kullanımı kolay olacak yöntemin sunulması gerekmektedir (7). Görme yetersizliği olan bireyler aynı zamanda bilgisayarı "ekran okuma programı" yardımıyla rahatlıkla kullanabildikleri için (9) bilgilenme açısından aile planlamasına yönelik yöntemlerin yer aldığı eğitim broşürleri ve kitapçıklara bilgisayar ortamında ulaşmaları sağlanabilir. Hemşireler kadınlara güvenilir seçenekleri değerlendirme konusunda bilgi vermelidir. Seçilen yöntemin kadının yaşam tarzına, kişisel tercihine ve yetersizlik derecesine uygun olması gerekmektedir. Ayrıca kadınların aile planlaması hizmetlerine erişim güçlüklerinin, erişenlerin karşılaştıkları olumsuz tutum ve yaklaşımların sağlık kuruluşları tarafından ele alınması, düzenlenen eğitimlere, eşlerinin de katılımının sağlanması yararlı olacaktır (16,26).

\section{Jinekolojik Muayene ve Kontroller ile İlgili Sorunlar ve Çözüm Yolları}

Ülkemizde hiçbir yakınması olmadan yalnızca kontrol olmak amacıyla hekime başvuran kadın oranının çok az olduğu belirtmektedir. Belirti olması genellikle bir hastalığın ilerlemiş bir safhaya geldiğini gösterir. Dolayısıyla hastalık ve tedavi maliyetleri artar ve yaşam kalitesi düşer. Bunun önlenmesi için düzenli jinekolojik muayene yaptırılmalıdır (27). Her kadının iyi bir hizmet alma hakkı vardır (33). Ancak yetersizliği olan kadınlar muayene ve taramalarını yaptırmakta ve hizmete erişmekte sıkıntılar yaşayabilmektedir (21). Kadınların düzenli kontrollere gitme davranışının daha az olmasının ana nedeni bilgilendirmenin az olması, buna bağlı olarak bilgi eksikliği ve anlayamadıkları bilimsel ifadelerin yarattığı korkudan kaynaklandığı düşünülmektedir (34). Yetersizliği olan kadınların serviks kanseri ve meme kanseri gibi kadın sağlığı ile ilgili yaşadığı riskler her kadın ile aynı olduğu için, jinekolojik kontrolleri de tüm kadınlara önerilen şekilde yapılmalıdır (22). Kadınların bu konuda bilgi sahibi olmaması, önemsememesi, utanması, sağlık kurumlarının erişim ve hizmet açısından yetersiz kalması, sağlık profesyonellerinin olumsuz tutumu ve bilgi yetersizliği, yaşanılan sıkıntıları arttırmaktadır. Yapılan araştırmalarda yetersizliği olan kadınların çoğunun, jinekolojik muayeneye gitmedikleri ve Pap smear testi yaptırmadıkları görülmüş, nedeninin ise çoğunlukla utanma, rahatsız edici bulma ve bilgi eksikliği olduğu saptanmıştır (25). Muayene eden bireyin tutumu ve deneyimi kadınların iyi ve doğru hizmet alması açısından önemlidir. Hemşirelerin etik açıdan işlem öncesi kendini tanıtması, hasta mahremiyetini ve haklarını koruması, işlem için izin alması, işlem sürecinde kadınlara doğru, yeterli ve anlayabileceği şekilde bilgi vermesi gerekmektedir (33). Görme yetersizliği olan kadınlara ulaşılabilir sağlık hizmeti sağlama ve bilgilendirme çalışmalarının artması oldukça önemlidir. Aynı zamanda sağlık hizmetlerinin ses kaydı, dokunsal materyal veya Braille alfabesi ile yazılmış materyallerle birlikte geliştirilmesi, ulaşılabilirliğin arttırılması gerekmektedir (34). Bununla birlikte sağlık kurumlarına erişimlerini kolaylaştırmak üzere kolay erişilebilir bir ön giriş, otomatik kapılar, rampa, engelsiz koridorlar, hissedilebilir zemin, erişilebilir tuvalet, otomatik ayarlı muayene masaları olması ve çevre düzeni sağlanması gerekmektedir. Asansörlerde seslendirme ve dokunsal butonlar bulunmalıdır. Görme yetersizliği olan kadınlara muayene için pozisyon verirken yavaş ve nazik olunmalı, uygulama öncesinde mutlaka yapılacak işlemler ve kullanılacak malzemeler açıklanmalıdır. Sağlık kurumlarında çalışan sağlık personeli deneyimli ve yeterli sayıda olmalı, kadının mahremiyetine özen göstermeli, benlik saygısına dikkat edilmelidir (22). Jinekolojik muayene için olumlu bir ilk deneyim sağlanması ve özgüvenlerinin arttırılması, 
Derleme

kadınların düzenli jinekolojik muayeneye gelmeleri açısından önemlidir. Muayene süresince kadının mahremiyetinin korunması, jinekolojik muayene masasının temiz ve düzenli olmasının sağlanması, muayene masasına çıkarken güvenliğinin sağlanması ve benzeri uygulamalar kadına yarar sağlayan uygulamalardır (33). Hemşireler bu noktada kadınla güvene dayalı bir iletişim kurmalı, pelvik muayene pozisyonuna kadın ile birlikte karar vermeli, muayene sırasında tüm işlemleri açıklamalı, muayene boyunca kadının yanında bulunup duygularını ifade etmesini, rahatlamasını sağlamalıdır. Ayrıca etik açıdan jinekolojik muayene sonrası kadınlara odadan çıkmadan, normal günlük perine bakımının nasıl yapılması gerektiğine dair yeni bilgilerin aktarılması, eski ve yanlış bilgilerinin düzeltmesi yarar sağlayacaktır $(28,33)$.

\section{Ĕ̈itim Alma ve Bakıma Yönelik Sorunlar ve Çözüm Yolları}

Birey, aile ve topluma sağlıklı yaşam alışkanlıklarının kazandırılmasında, sağlığı koruma, sürdürme ve geliştirmede eğitim önemli bir yer tutmaktadır. Bireye uyumlu olacak şekilde, kendi kendine bakımını sağlayabilmesi için etkili bir eğitim programı planlanması ve uygulanması önem taşımaktadır (35). Özellikle jinekolojik ve obstetrik sorunlarla ilgili sağlı eğitiminde durum daha da hassaslaşmakta, görme yetersizliği olanlara yönelik Braille alfabesiyle yazılı bilgilendirme sistemi eksik kalmakta ve mevcut kaynakların gören insanlara yönelik olduğu görülmektedir (36). Görme yetersizliği olan bireyler, farklı bir yaklaşıma ihtiyaç duydukları için üreme sağlığı ve cinsel sağlık ile ilgili bilgiye erişmekte zorluklar yaşamaktadır (34).

Görme miktarı bireylerin eğitim alma şekillerini etkilemektedir (37). Bu nedenle sağlık profesyonellerinin görme yetersizliğinin nedenlerini sorgulaması ve bilgi sahibi olması gerekmektedir. Kalıtsal hastalıkların çoğunda retina hücrelerinin eksik çalışmaları sonucu körlük oluşmaktadır. Bu bağlamda, görme taraması tüm yenidoğanların muayenesinin bir parçası olup, erken tanı önem taşımaktadır $(9,37)$. Yenidoğan döneminde ve takiben tüm muayenelerde göz değerlendirmesinin bir basamağı olarak kırmızı refle testi yapılması önerilmektedir. Kırmızı refle testi, görme ve katarakt, glokom, retinoblastom, retina hastalıkları, oküler bulgusu olan sistemik hastalıkların ve yüksek dereceli kırma kusurlarının ortaya çıkarılmasını sağlamaktadır (37). Hemşireler, görme yetersizliği olan anne adaylarını, görme kaybına sıklıkla neden olan faktörler ve yenidoğan tarama testleri konusunda bilgilendirmelidir.

$\mathrm{Bu}$ derlemede, görme kaybına sıklıkla neden olan retinitis pigmentosa, diyabetik retinopati, katarakt, glokom ve göz travmaları hakkında aşağıdaki bilgiler sunulmuştur.

Diyabetik Retinopati: Diyabetik retinopati, diabetes mellitusa bağlı gelişen en yaygın mikrovasküler komplikasyondur. Diyabetik olguların \%4,6-\%10'unda retinopatiye bağlı görme kayb1 gelişmektedir. Diyabetik retinopatinin küçük retina damarlarını, arteriyolleri, kapilleri ve venleri etkilemesiyle retinada kanama, sıvı sızması ve tıkanma sonucu görme yetisinde azalma meydana gelmektedir. Gelişmiş ülkelerde genç yetişkinler ve çalışma çağındaki nüfusta edinsel körlüğün önde gelen nedenlerinden biridir (39).

Katarakt: Katarakt dünyada körlüğün en önemli nedeni olup, doğuştan veya sonradan meydana gelebilmektedir. En fazla gelişmekte olan ülkelerde olmak üzere çoğu kişi katarakt nedeni ile görememektedir. Düşük gelir düzeyindeki ülkelerde, korneal skar gelişimi ile seyreden vitamin A eksikliği, kızamık enfeksiyonu, oftalmia neonatorum, gelişmiş ülkelerde santral sinir sistemine ve retinaya bağlı patolojiler, orta gelir düzeyindeki ülkelerde ise katarakt etiyolojik nedenler arasında ön plana çıkmaktadır. Çocukluk çağı körlüğünün önemli nedenlerinden biri pediatrik katarakt iken yetişkin diabetik bireylerde görülen en erken komplikasyon diyabetik katarakt olmaktadır (40).

Glokom: Halk arasında göz tansiyonu olarak bilinen glokom, retinal ganglion hücrelerinin progresif dejenerasyonu ile karakterize olan optik sinir üzerinde hasara yol açan ve görmeyi de etkileyerek körlüğe neden olan bir optik nöropatidir. Glokom, dünya çapında 70 milyondan fazla insanı etkilemekte, geri dönüşü olmayan körlüğün önde gelen nedeni arasında sayılmaktadır (41).

Göz Travmaları: Tüm göz travmalarının \%90'ı önlenebilir nedenlere bağlıdır. Ancak, 15 yaş altı çocukların en fazla hastaneye başvuru nedeni arasında göz travması yer almaktadır. Nadiren ölümcül olduğundan tedavisi ihmal edilmekte, bireyin yaşam kalitesini olumsuz etkilemektedir. Çocukluk dönemindeki göz travmalarının önemli bir morbidite nedeni olduğu unutulmamalı ve önemi göz ardı edilmemelidir (41).

\section{Hemşirenin Rolü}

Hemşireler, görme yetersizliğinin nedenleri ve bu bireylerin özel eğitime gereksinimi olduğunun farkına varıp, üreme sağlı̆̆1 ve cinsel sağlığa yönelik eğitim programları geliştirmelidir (42). Üreme sağlığı ile ilgili konularda verilecek olan eğitimlerde konferans, tartışma, soru/cevap, demonstrasyon, simülasyon ve danışmanlık gibi eğitim yöntemlerinden yararlanılabilir (21). Ancak sağlık profesyonellerinin görme yetersizliği olan bireye yaklaşım konusunda bilgisi yetersiz kalmakta, aktarılan bilgiler yüzeysel bir şekilde iletilmekte ve görme yetersizliği olan bir birey için durumun çok daha zor hale geldiği görülmektedir (36). Hemşirelerin yaklaşımı, kadınların sağlık hizmetlerinden optimal düzeyde yararlanabilmeleri açısından oldukça önemlidir. Bu nedenle hemşirelerin deneyimli ve bilgili olması, bilgilerinin güncel tutulması amacıyla da sürekliliği olan hizmet içi eğitimlerin sağlanması gerekmektedir. Ayrıca, görme yetersizliği olan bireylere yaklaşım konusunda hemşireler lisans düzeyinden itibaren bilinçlenmeli, etkili iletişim kurma, olumlu tutum ve davranış geliştirme konularında eğitim almalı, kadınlarla daha iyi ilişki kurabilmeleri ve daha aktif olmaları konusunda cesaretlendirilmelidir (42).

Görme yetersizliği olan kadınlar hemşirelerden; anlayışlı, açıklayıcı, bilgi verici olmalarını, aşırı korumacı olmamalarını, tedavi ve bakıma ilişkin yakınlarına değil kendilerine bilgi vermelerini, ihtiyaçları doğrultusunda destek olmalarını, mahremiyete özen göstermelerini beklemektedir. Eğitim verici rolü olan hemşireler, görme yetersizliği olan kadınlara bütüncül olarak yaklaşmalı ve üreme sağlığı ve cinsel sağlığa yönelik bilgi ve danışmanlık sağlamalıdır $(27,42)$.

$\mathrm{Bu}$ bağlamda ulusal ve uluslararası literatür tarandığında, görme yetersizliği olan kadınlarda üreme sağlığı hizmetlerini geliştirmeye yönelik çoğunlukla tanımlayıcı tipte çalışmalar yapıldı̆̆ı, çalışmaların genel olarak tüm engel türlerini kapsayacak şekilde olduğu, girişimsel tipteki çalışmaların ise çok az olduğu görülmektedir. Ülkemizde Yaşar ve arkadaşları (2017) 84 
Derleme

kadında genital hijyen bilgi ve uygulamalarını araştırmış, görme yetersizliği olan kadınların genital hijyen konusunda bilgi eksikliği olduğu belirtilmiştir (25). Dündar ve Özsoy (2020) 187 kadının menstrual hijyen yönetimlerinin nasıl olduğunu araştırmış, yaklaşık yarısının bu dönemi bağımsız yönetemediği, menstruasyon dönemindeki hijyen uygulamalarının istendik düzeyde olmadığı, menstruasyonun başlama ve bitişini anlamada farklı belirteçler kullandığı ve bazı kadınların sosyal yaşantılarının etkilendiği belirtilmiştir (23). Ülkemizde görme yetersizliği olan kadınlar ile yapılan bazı çalışmalar tez çalışması olup, yayınlanmış makalesine ulaşılamadığı için dergi yazım kuralları gereği burada yer verilememiştir. Cavalcante ve arkadaşları (2013) Brezilya'da görme engelli kadınlara kadın kondomunun nasıl kullanılacağını öğretmek için materyal geliştirip, bu konudaki bilgilerini arttırmışlardır. Kadınların üreme sağlığı ve cinsel sağlığa yönelik bilgilerinde eksiklikler ve yanlış bilgiler olduğu, geliştirilen materyal ile kadın sağlığı konusunda bilgilenmeye destek sağlandığı için girişimin etkili olduğu belirtilmiştir (34). Abd-El Sattar ve Abd-El Aal’ın (2015) Kahire'de adölesan görme yetersizliği olan kadınlar ile yaptığı çalışmada, beslenme, kişisel hijyen, egzersiz, uyku ve üreme sağlığı konularını içeren sağlık eğitimi verilmiştir. Yapılan eğitim sonrası eğitimin ilgili konularda bilgi düzeyini arttırdığı bulunmuştur (43).

Ülkemizde ve yurtdışında yapılan çalışma örnekleri incelendiğinde, ortak sonuç olarak görme yetersizliği olan bireylerin üreme sağlığı bilgilerinin istendik düzeyde olmadığı, eğitime ihtiyaç duydukları görülmektedir. Üreme sağlı̆̆ına yönelik girişimsel çok az çalışmaya rastlanılmaktadır. Bu bağlamda, görme yetersizliği olan kadınlara yönelik uygulamalı üreme sağlığ1 eğitimlerinin düzenlenmesi, eğitim materyali geliştirilmesi yönünde deneysel çalışmalar yapılması gerekmektedir.

\section{Sonuç}

Literatür taramaları sonucu görme yetersizliği olan bireylerde üreme sağlığı ve cinsel sağlığa yönelik saptanan temel sorunların menstrual siklus yönetimi ve hijyen, cinsel sağlık, gebelik, doğum, emzirme ve aile planlaması konularında bilgi eksikliği, jinekolojik kontrollerin ihmali, sağlık hizmetine erişimde yaşanan güçlükler ve sağlık profesyonellerinin olumsuz tutumuna ilişkin sorunlar olduğu görülmektedir. Görme yetisinin azalması ya da tamamen kaybolmasının öğrenmede yarattığı güçlük ve buna bağlı görme yetersizliği olan kadınlara yönelik farklı türde eğitim planlanmasının gerekliliği vurgulanmaktadır. Çözüm önerisi olarak en başta hemşirelerin görme yetersizliği olan bireylerle etkili iletişim kurabilmeleri gerekmektedir. Hemşirelerin yaklaşımı, kadınların sağlık hizmetlerinden optimal düzeyde yararlanabilmeleri açısından oldukça önemlidir. Bu bağlamda iletişim engellerini ortadan kaldırmak için ön yargıları kırmak, engelli bireyleri yok saymamak, kişisel alanlarına saygı göstermek, açıklayıcı bilgilerle, yönlendirerek yardım etmek önem arz etmektedir. Üreme sağlığına yönelik kaygıların giderilmesi adına eğitimlerde ve muayenelerden önce açıklama yapılması, kullanılacak olan materyal örneklerine kadınların dokunmalarına izin verilerek tanıtılması yararlı olacaktır. Görme yetersizliği olan kadınlara üreme sağlığına yönelik eğitim ve danışmanlık verilirken, işitsel, dokunsal ve kokusal maket ve materyallerin kullanılması, Braille alfabesi ile yazılmış broşürlerin olması, seslendirilmiş broşürlerin, kitapçıkların sayıca yeterli olması ve inovatif materyaller geliştirilmesi gerektiği düşünülmektedir. Üreme sağlı̆̆ına yönelik danışmanlık rolü olan hemşirelerin bu alanda eğitim verebilmek üzere desteklenmeleri gerekmektedir. Hemşirelerin deneyim kazanmaları ve bilgi sahibi olmaları amacıyla özel eğitim kurumları ile iş birliği kurulması, görme yetersizliği olan bireylere yaklaşım ve danışmanlık konusunda eğitimler düzenlenmesi ve devamlılı̆̆ının sağlanması önerilir.

\section{Bilgilendirme}

Yazarların katkı oranı beyanı şöyledir: Fikir/kavram: AT, ÖDB; Tasarım: AT, ÖDB; Denetleme/danışmanlık: ÖDB; Kaynak taraması: AT, ÖDB; Derlemenin yazımı: AT, ÖDB. Derlemenin tüm aşamalarında yayın etiğine uyulmuştur. Araştırmacılar arasında herhangi bir çıkar çatışması bulunmamaktadır.

\section{Kaynaklar}

1. World Health Organization (WHO). International classification of impairments, disabilities and handicaps: A manual of classification relating to the consequences of disease, WHO. Geneva. WHO; World report on disability, 2014. URL: http://whqlibdoc.who.int/publications/1980/9241541261_eng.pdf. 20 Ocak 2020

2. Yıldız S, Gürler S. Görme engelli bireylerin engelli haklarına dair bilgi düzeylerinin ölçülmesi-Ankara örneği. Kırıkkale Üniversitesi Sosyal Bilimler Dergisi 2018;8(1):241-268.

3. World Health Organization (WHO). World health statistics 2017: Monitoring health for the SDGs, Sustainable Development Goals. World Health Organization, Geneva, 2017.

4. Türkiye İstatistik Kurumu (TÜIKK). Dünya nüfus günü [haber bülteni]. 2015 Basım. URL: http://www.tuik.gov.tr/PreHaberBultenleri.do?id=18617. 26 Kasım 2019

5. T.C. Aile, Çalışma ve Sosyal Hizmetler Bakanlığı, Engelli ve Yaşlı Hizmetleri Genel Müdürlüğü. Engelli ve yaşlı istatistik bülteni. 2019. URL: https://ailevecalisma.gov.tr/media/6598/bu-lten_may\%C4\%B1s2019_20190624-1.pdf. 01 Haziran 2020

6. United Nations. United Nations convention on the rights of persons with disabilities, 2006:1-28. URL: http://www.un.org/esa/socdev/enable/rights/convtexte.htm. 20 Ocak 2020

7. Kokanalı D, Karaca M, Özel Ş, Engin Üstün Y. Engelli kadınlarda üreme sağlığı. Jinekoloji- Obstetrik ve Neonatoloji Tıp Dergisi 2018;15(1):28-30.

8. World Health Organization (WHO). World Health Organization 2011: World Report on Disability 2011, Geneva. URL: https://www.who.int/disabilities/world_report/2011/report.pdf. 01 Haziran 2020

9. T.C. Aile ve Sosyal Politikalar Bakanlığı Engelli ve Yaşlı Hizmetleri Genel Müdürlüğü. Aile eğitim rehberi, görme engelli çocuklar. Ankara, Grafer Tasarım Baskı Ambalaj; 2014:1-104. 
Derleme

10. Kamış Ö, Demir E. Görme yetersizliği olan lisans öğrencilerinin sınıf içi ölçme-değerlendirme süreçlerinin incelenmesi. Ankara Üniversitesi Eğitim Bilimleri Fakültesi Özel Eğitim Dergisi 2018;19(3):423-450. DOI: 10.21565/ozelegitimdergisi.334802.

11. Milli Eğitim Bakanlığı (MEB) (2013). Çocuk gelişimi ve eğitimi. Görme engelliler. Ankara, 2013.

12. Hacettepe Üniversitesi Nüfus Etütleri Enstitüsü. 2018 Türkiye nüfus ve sağlık araştırması (TNSA). Hacettepe Üniversitesi Nüfus Etütleri Enstitüsü, T.C. Cumhurbaşkanlığı Strateji ve Bütçe Başkanlığı ve TÜBİTAK, Ankara, Türkiye, 2019.

13. İnandı T, Savaş N, Arslan E, Yeniçeri A, Peker E, Alışkın Ö ve ark. Hatay’da akraba evliliği sıklığı, nedenleri, çocuk sağlığı, ilişkilerde mutluluk ve yaşam doyumu. Türkiye Halk Sağlığı Dergisi 2016;14(1):43-55.

14. Bolat N, Doğangün B, Yavuz M, Demir T, Kayaalp L. Doğuştan tam görme engeli olan ergenlerin depresyon, kaygı düzeyleri ve benlik kavramı özellikleri. Türk Psikiyatri Dergisi 2011;22:77-82.

15. Cumurcu BE, Karlıdağ R, Almış BH. Fiziksel engellilerde cinsellik. Psikiyatride Güncel Yaklaşımlar 2012;4(1):84-98.

16. Timur S, Ege E, Bakış E. Engelli kadınların üreme sağlığı sorunları ve etkileyen faktörler. Cumhuriyet Üniversitesi Hemşirelik Yüksekokulu Dergisi 2006;10(1):51-58.

17. Murthy GVS, John N, Sagar J. South India disability evidence study group reproductive health of women with and without disabilities in South India, the SIDE study (South India Disability Evidence) study: A case control study. BMC Womens Health 2014;14(146):1-7.

18. Hosseinpoor AR, Williams JAS, Gautam J. Socioeconomic inequality in disability among adults: a multicountry study using the world health survey. Am J Public Health 2013;103:1273-1286.

19. Bezzera CP, Pagliuca LM. The experience of sexuality by visually impaired adolescents. Rev Esc Enferm USP 2010; 44(3):577-582.

20. Bozkurt ÖD, Parlakyıldız E, Küççük M, Emektar D, Gerekli B, Koç B ve ark. Görme engelli kadınların üreme sağlığı sorunları ve sağlık çalışanlarından beklentileri: Hemşirelik öğrencileri ekip çalışması. 18. Ulusal Hemşirelik Öğrencileri Kongresi; 25-27 Nisan 2019; Afyonkarahisar.

21. Dündar T, Özsoy S. Menstrual hijyen ve görme engelliler. Hemşirelikte Eğitim ve Araştırma Dergisi 2018;15(3):192-194. DOI:10.5222/HEAD.2018.192.

22. Güngör İ. Engelli kadınlarda üreme sağlığı. İçinde Kızılkaya Beji N, Hemşire ve Ebelere Yönelik Kadın Sağlığı ve Hastalıkları. Genişletilmiş 2. Baskı. Nobel Tıp Kitabevi; 2017:171-201.

23. Dündar T, Özsoy S. Menstrual hygiene management among visually impaired women. British Journal of Visual Impairment 2020; 1-16. 0264619620911441. DOI: 10.1177/0264619620911441. 01 Haziran 2020

24. Kanmani K, Ravisankar AK. Prevalence of menstrual problems and treatment-seeking behavior: A study among visually challenged women. International Journal of Scientific and Research Publications 2016;6(1):621-624.

25. Yaşar BN, Terzioğlu F, Koç G. Knowledge and practices of genital hygiene: visual-disabled women sample. Dokuz Eylül Üniversitesi Hemşirelik Fakültesi Elektronik Dergisi 2017;10(3):123-130.

26. Yimer AS, Modiba LM. Modern contraceptive methods knowledge and practice among blind and deaf women in Ethiopia. A cross-sectional survey. BMC Womens Health 2019;19:151.

27. Daşıkan Z, Sevil Ü. Kadınlarda jinekolojik muayeneyi engelleyen psikososyal faktörler. STED 2017;26(2):75-83.

28. Duman M. Engelli bireylerin üreme sağlığı sorunları. İçinde Timur Taşhan S, Erci B, Her Yönüyle Engellilik. 1. Basım. Anadolu Nobel Tıp Kitabevleri; 2018:274-299.

29. Şat SÖ, Erenel AŞ, Sözbir ŞY. Özellikli gruplarda kontrasepsiyon danışmanlığı. SDÜ Sağlık Bilimleri Enstitüsü Dergisi 2019;10(2):190-197.

30. Bloom TL, Mosher W, Alhusen J, Lantos H, Hughes RB. Fertility desires and intentions among U.S. women by disability status: findings from the 2011-2013 national survey of family growth. Matern Child Health J 2017;21(8):1606-1615. DOI: 10.1007/s10995-016-2250-3.

31. Tejeji MY, Assefa B, Kedebe T, McDowell M, Tenaw E. Assessment on family planning needs of people living with disabilities: Case of Addis Ababa, Ethiopia, 2017. https://www.fhi360.org/sites/default/files/media/documents/resource-disability-report.pdf. 20 Ocak 2020

32. Tanabe M, Nagujjah Y, Rimal N, Bukania F, Krause S. Intersecting sexual and reproductive health and disability in humanitarian settings: risks, needs, and capacities of refugees with disabilities in Kenya, Nepal, and Uganda. Sex Disabil 2015;33(4):411-27.

33. Sarpkaya D, Vural G. Hemşirelikte dört bilme yolunun jinekolojik muayenede kullanımı. Dokuz Eylül Üniversitesi Hemşirelik Fakültesi Elektronik Dergisi 2014;7(2):124-127.

34. Cavalcante LDW, Barbosa GOL, Oliveira PMP, Rebouças CBA, Pagliuca, LMF. Assistive technology for visually impaired women: usage of female condoms- a descriptive study. Online Brazilian Journal of Nursing 2013;12(2):534-545.

35. Arslan ŞF, Coşkunol H. Sağlık profesyonelinin eğitim rolü: Alkol ve madde bağımlılarında sağlıklı yaşam biçimi davranışı geliştirme eğitimi. Tıp Eğitimi Dünyası, 2016;15(47):13-20.

36. Lee K, Devine A, Marco MJ, Zayas J, Gill-Atkinson L, Vaughan C. Sexual and reproductive health services for women with disability: A qualitative study with service providers in the Philippines. BMC Women's Health 2015;15:87.

37. Altunhan H, Yılmaz FH. Yenidoğanın değerlendirilmesi ve yenidoğan taramaları. Turkiye Klinikleri J Fam Med-Special Topics 2018;9(1)28-32.

38. Özmert E. The first scientifically approved bionic eye now available in Turkey. The Journal of Retina\&Vitreous 2015;23(1):92-95.

39. Akkaya S, Açıkalın B, Asılyazıcı E, Yılmaz A, Yamiç M, Kocapınar Y. Diyabetik Retinopatinin Tanı ve Tedavisi. The Journal of Retina\&Vitreous 2018;27(4):390-401. 
Derleme

40. Ayyıldız Ö, Özge G, Küçükevcilioğlu M, Akincioğlu D, Uludağ HA, Mutlu FM. Pediatrik kataraktlı hastalarımızda klinik özellikler ve cerrahi sonuçlar. The Journal of Glaucoma\&Cataract 2017;12:21-25.

41. Weineb RN, Aung T, Medeiros FA. The pathophysiology and treatment of glaucoma: A review. JAMA 2014;311(18):19011911. DOI:10.1001/jama.2014.3192.

42. Mitra M, Long-Bellil LM, Smeltzer SC, Iezzoni LI. A perinatal health framework for women with physical disabilities. Disability and Health Journal 2015;8(4):499-506.

43. Abd-El Sattar RA, Abd-El Aal EM. Effect of health educational program for female blinded adolescent students regarding reproductive health. American Journal of Nursing Science 2015;4(1):1-8. DOI: 10.11648/j.ajns.20150401.11. 